\title{
Comparative Efficacy between Intravenous Iron and Oral Iron on Enhancing Hemoglobin Level among Pregnant Women with Iron Deficiency Anemia in Low and Middle Income Countries: A Meta-Analysis
}

\author{
Fiki Cahya Ningrum', Bhisma Murti 1), Vitri Widyaningsih²) \\ 1) Masters Program in Public Health, Universitas Sebelas Maret \\ 2) Faculty of Medicine, Universitas Sebelas Maret
}

\begin{abstract}
Background: Iron deficiency was a major cause of anemia in pregnancy. The incidence of large deficiency anemia was mostly experienced in pregnancy which can result in general hematological disorders with considerable complications both for the mother and the fetus. This study aimed to compare the efficacy of intravenous iron administration and oral iron for the treatment of iron deficiency anemia in pregnancy.

Subjects and Method: This was a meta-analysis conducted using PRISMA systematic guidelines. The process of searching articles was carried out between 2000 and 2018 using a database search engine consisting of; PubMed, Science Direct, Springer Link, and Google Scholar. Based on database searches, nine articles that met the Randomized Control Trial (RCT) criteria and study were conducted in lower middle income countries. This study involved 967 samples divided into two groups of 484 intravenous iron and 483 oral iron. The analysis was carried out with Review Manager (RevMan) software 5.3. The results were assessed for Mean Difference (MD) and the analysis was carried out for heterogeneity.

Results: There was a high heterogeneity between experiments $\left(I^{2}=91 \%\right.$; $\left.p<0.001\right)$ so that Random Effects Model (REM) was used. Intravenous iron administration can increase hemoglobin levels $0.70 \mathrm{~g} / \mathrm{dL}$ higher than oral iron administration, and it was statistically significant (MD 0.70; 95 \% CI: 0.37 to $1.02 ; \mathrm{p}<0.001$ ).

Conclusion: Intravenous iron administration was more effective than oral iron for the treatment of iron deficiency anemia in pregnancy. Pregnant women given intravenous iron more quickly reach the desired hemoglobin level target than oral iron.
\end{abstract}

Keywords: anemia, iron deficiency, intravenous iron, oral iron, meta-analysis

\section{Correspondence:}

Fiki Cahya Ningrum. Masters Program in Public Health, Universitas Sebelas Maret. Jl. Ir. Sutami 36A, Surakarta 57126, Central Java. Email: ningrum.fiki@gmail.com. Mobile: o81216494956.

\section{BACKGROUND}

Anemia in pregnancy is the most common and wide spread public health problem, anemia is estimated to affect almost $40 \%$ of pregnancies worldwide and is associated with a significant increased risk of perinatal morbidity and mortality (Haider et al., 2013). Anemia affects globally 1.62 billion people worldwide, associated with $24.8 \%$ of the world's population (Pavord et al., 2012).
Anemia has been defined as a limit of hemoglobin levels in pregnancy. The World Health Organization (WHO) defines anemia as a hemoglobin level < $11 \mathrm{~g} / \mathrm{dL}$ while in pregnancy $<10 \mathrm{~g} / \mathrm{dL}$ in the first trimester, $<10.5 \mathrm{~g} / \mathrm{dL}$ in the second trimester and 10 $\mathrm{g} / \mathrm{dL}$ in the third trimester, in recognition of the maximum physiological hemodilution in the second trimester (Pavord et al., 2012). 
Based on global data, $56 \%$ of pregnant women are in low status and middle and lower income countries are anemic (Pasricha et al., 2013). Anemia is one of the risk factors that contribute to $50 \%$ of maternal deaths (Khaskheli et al., 2016). Pregnant women are the population most vulnerable to developing iron deficiency anemia. Health interventions have been carried out on a large scale, but the incidence of iron deficiency anemia continues to increase in developing countries (Bilimale et al., 2010).

Pregnancy requires a lot of iron, as the pregnant women have the risk of developing iron deficiency anemia. During pregnancy, iron deficiency anemia is associated with an increased risk of preterm birth, low birth weight, fetal growth restriction, and increased and maternal mortality. Iron deficiency can also cause a person to experience postpartum iron deficiency anemia, peripartum which can trigger heart failure and infection (Camaschella, 2015).

Supplements are needed for pregnant women who are anemic or non-anemic such as iron, folic acid or both. Based on the route of administration of iron can be taken orally and intravenous injection (II) which is generally used clinically in practice (Qassim et al., 2017). Additional supplements are needed for pregnant women with anemia. To prevent iron deficiency in pregnancy, experts recommend consuming 30 mg of iron every day (Rahman et al., 2016).

The use of oral iron is considered to be the first treatment due to low temperature and low cost, but its use is limited by gastrointestinal side effects that can affect compliance and low absorption rates. Intravenous iron is considered to be a useful option when rapid handling is needed (Qassim et al., 2017). Fear of anaphylaxis (no formulation that has the highest level of safety of the Food and Drug Administration or FDA) in intravenous (II) use no adverse side effects have been reported in thousands of patients (Tolkien et al., 2015).

Recently, the Cochrane Collaboration reported that high incidence and high disease burden associated with iron deficiency anemia in pregnancy have a lack of trials of the quality of the effects of maternal and neonatal clinical administration of iron in women with anemia (Reveiz et al., 2012). Iron deficiency in pregnant women affects growth and brain development, cognitive, neonatal behavior (Congdon et al., 2012). The negative effects of iron deficiency anemia during childbirth are associated with an increased risk of Sectio Caesarea (SC) which adversely affects neonatal (Drukker et al., 2015).

This study aimed to examine the efficacy of intravenous iron administration than oral iron on hemoglobin levels in pregnant women with iron-deficiency anemia in lower middle income countries.

\section{SUBJECTS AND METHOD \\ 1. Study Design}

This was a systematic review and meta-analysis. The articles in this study were obtained from database of several indexes included; PubMed, Science Direct, Springer Link, and Google Scholar. The articles were published between 2000 and 2018. Searching was using the following keywords: "Pregnancy" AND "anemia, iron deficiency", "oral iron", "intravenous iron”, "intravenous iron therapy", "Pregnancy", "anemia", "treatment", "randomized control trial", "iron sucrose", "anemia in pregnancy", "treatment of anemia in pregnancy" AND "intravenous iron inpregnancy", "MeSH".

data of this study is published articles between 2000 and 2018 which the study was carried out in lower middle income countries found in the databases which were; PubMed, Science Direct, Springer Link, and Google Scholar. 


\section{Inclusion Criteria}

The inclusion criteria in this study were full paper articles with Randomized Controlled Trial (RCT), therapy oral iron with comparised of intravenous substance therapy, and pregnant women with anemia (hemoglobin level $<10.5 \mathrm{~g} / \mathrm{dL}$ ). Articles with hemoglobin levels measured after 4 weeks.

\section{Exclusion Criteria}

The study was conducted in cross section, case control, quasi experimental, study protocol or pilot study. The therapy given compared between 2 II and 2 oral.

\section{Definition of Operational Variables} Anemia was defined as the limit of hemoglobin levels in pregnancy. The World Health Organization (WHO) defines anemia as a hemoglobin level <11g / dL while in pregnancy $<10 \mathrm{~g} / \mathrm{dL}$ in the first trimester, $<10.5 \mathrm{~g} / \mathrm{dL}$ in the second trimester and 10 $\mathrm{g} / \mathrm{dL}$ in the third trimester, in recognition of the maximum physiological hemodilution in the second trimester (Pavord et al., 2012).

This study involved two treatment groups that would be compared. The intravenous group includes iron sucrose, ferric carboxymaltose, and LWM iron dextran, the iron group orally includes ferrous sulfate, ferrous fumerate, and ferrous ascorbate. The scale of measurement of results from intravenous and oral were presented in the form of continuous data.

\section{Data Analysis}

Data analysis was carried out by using the Review Manager (Rev-Man) software 5.3 released by the Cochrane Collaboration. RevMan is used to calculate Mean Difference (MD) as a whole.

\section{RESULTS}

There were 815 identified articles which can be seen in Figure 1. After going through the multiple article deletion process, 29 articles were found, the filtered articles were 786 articles. Based on the results of the filtered article, there were 761 articles that must be issued and 25 articles that were considered to fulfill the requirements for full text review process.

After an assessment of full text articles, articles were found that were targeted not for pregnant women but for women before pregnancy and post partum mothers. The outcome of the study did not match the criteria applied, the article was issued because it did not include the treatment time.

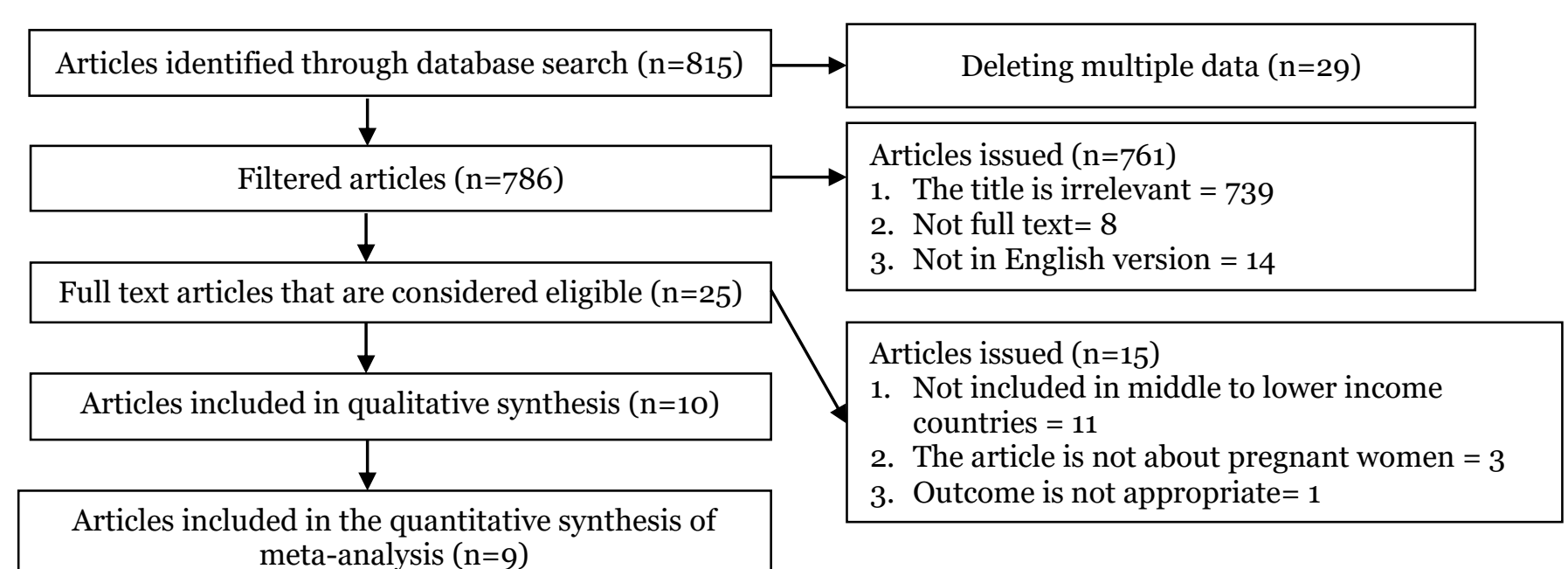

Figure 1. Flowchart Review Process 
Articles that fulfilled the qualitative requirements were reviewed and one article was issued because it did not include the average after treatment and standard deviation (SD) needed to determine the effects of treatment. The article only included the difference in improvement after treatment so that analysis cannot be done by using mean difference (MD).

From the final results of the article review process, there were 9 articles that fulfilled the quantitative requirements to conduct a meta-analysis of intravenous iron efficacy compared to oral iron on increased hemoglobin levels in pregnant women with iron-deficiency anemia. Articles obtained from the results of the review were studies originating from countries included in middle and lower income countries.

The following was an overview of the study area obtained from articles that have fulfilled the requirements: India, there were eight studies conducted in India. In addition, there was one study conducted in the country of Egypt. Based on the description, the regions included in middle and lower income countries can be seen in Figure 2. to find out the map of the area and the number of study subjects included in the meta-analysis.

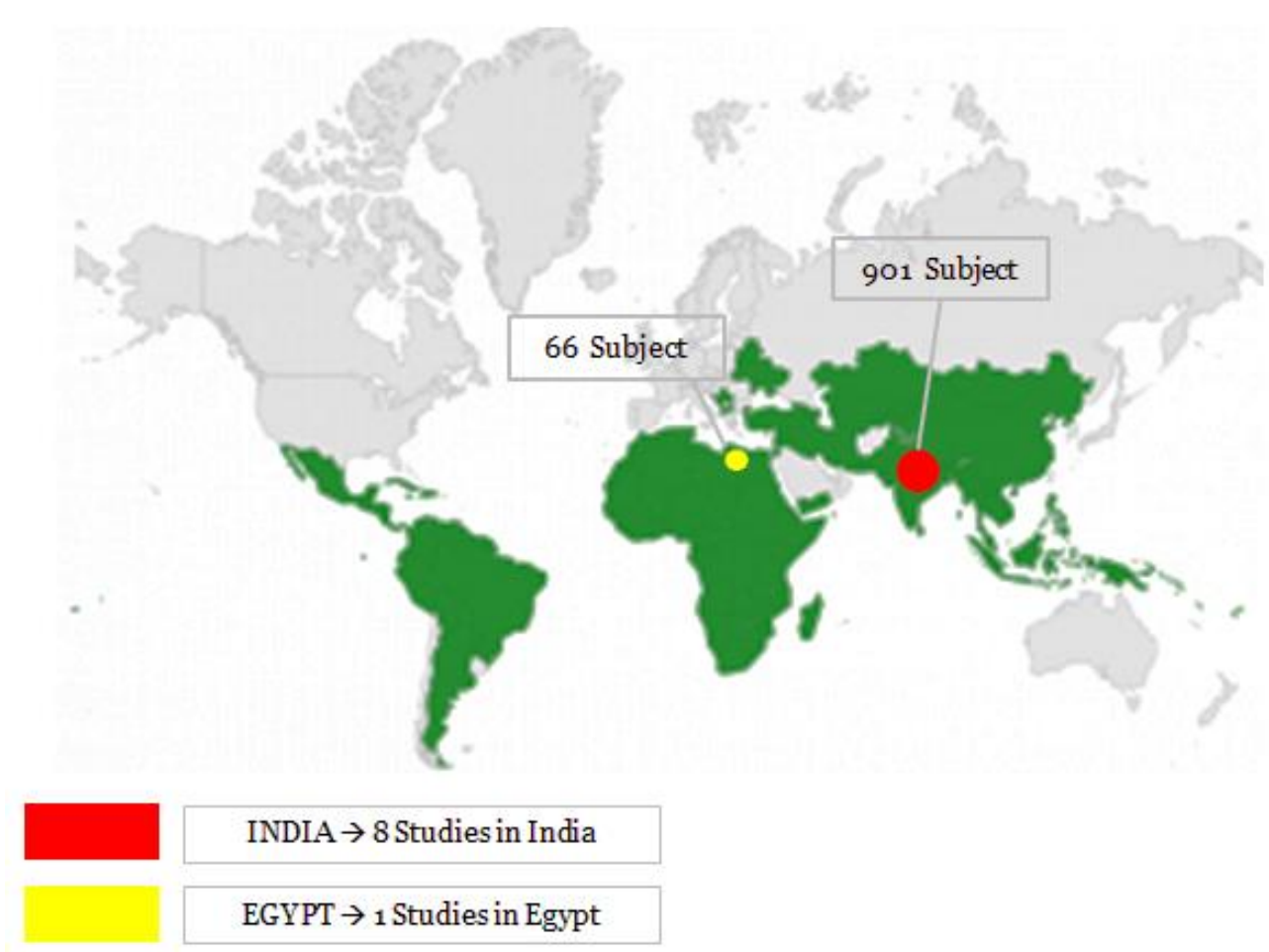

Figure 2. General Description of the Study Area

Based on Figure 2, in the middle to lower income countries included in this metaanalysis, it consisted of only two countries, namely India and Egypt. The Indian countries included in the subject of this study consisted of 901 pregnant women with iron-deficiency anemia and in Egypt there were 66 pregnant women who were included in the study subjects to see the efficacy of intravenous iron administration compared to oral iron against increased hemoglobin levels in anemia pregnant women with deficiency iron. 
The results of the meta-analysis were presented in forest plot. The forest plot presented a diagram that showed information from each study studied and estimates of overall results (Akobeng in Murti, 2018). In addition, this meta-analysis also presented a funnel plot, a diagram that illustrated the possibility of publication bias by displaying the relation between the effect size of the study and the sample size of the various studies.

The publication bias in the funnel plot can be assessed by looking at the funnel shape asymmetry, the number of points on the right and left side compared to the standard error (Murti, 2018).

Table 1. Summary source of intravenous iron compared to oral iron to increased hemoglobin levels

\begin{tabular}{|c|c|c|c|c|c|c|c|c|}
\hline \multirow{2}{*}{$\begin{array}{c}\text { Author and } \\
\text { Year }\end{array}$} & \multirow{2}{*}{$\begin{array}{l}\text { Location/ } \\
\text { Country }\end{array}$} & \multicolumn{2}{|c|}{ Total } & \multirow{2}{*}{$\begin{array}{c}\text { Population } \\
\text { Source }\end{array}$} & \multirow{2}{*}{$\begin{array}{c}\text { Inclusion } \\
\text { Criteria } \\
(\mathrm{Hb}, \mathrm{g} / \mathrm{dL})\end{array}$} & \multirow[b]{2}{*}{ Content } & \multicolumn{2}{|c|}{ Result } \\
\hline & & II & Oral & & & & $\mathbf{I V}$ & Oral \\
\hline $\begin{array}{l}\text { Abhilashi, et } \\
\text { al.(2014) }\end{array}$ & $\begin{array}{l}\text { Pondicherr } \\
\mathrm{y}, \text { India }\end{array}$ & 50 & 50 & $\begin{array}{l}\text { JIPMER in the } \\
\text { Department of Obs- } \\
\text { tetrics and Gynae- } \\
\text { cology }\end{array}$ & $6.0-8.0$ & $\begin{array}{l}\text { IV: iron } \\
\text { sucrose } \\
\text { Oral: ferrous } \\
\text { sulfate }\end{array}$ & $\begin{array}{c}\text { Mean: } \\
9.48 \\
\text { SD: } \\
0.7\end{array}$ & $\begin{array}{c}\text { Mean: } \\
9.15 \\
\text { SD: } \\
0.7\end{array}$ \\
\hline $\begin{array}{l}\text { Bhavi, et al. } \\
\text { (2017) }\end{array}$ & India & 56 & 56 & $\begin{array}{l}\text { Antenatal clinic at } \\
\text { Shri B.M.Patil } \\
\text { Medical college } \\
\text { Hospital, Bijapu }\end{array}$ & $7.0-11.0$ & $\begin{array}{l}\text { IV: iron } \\
\text { sucrose } \\
\text { Oral: ferrous } \\
\text { fumarate }\end{array}$ & $\begin{array}{l}\text { Mean: } \\
10.64 \\
\text { SD: } \\
1.3\end{array}$ & $\begin{array}{l}\text { Mean: } \\
10.06 \\
\text { SD: } \\
1.03\end{array}$ \\
\hline $\begin{array}{l}\text { Darwish, et } \\
\text { al. (2017) }\end{array}$ & $\begin{array}{l}\text { Assiut, } \\
\text { Egypt }\end{array}$ & 33 & 33 & Assiut University & $7.0-10.0$ & $\begin{array}{l}\text { IV: LMW iron } \\
\text { dextran } \\
\text { Oral: ferrous } \\
\text { fumerate }\end{array}$ & $\begin{array}{l}\text { Mean: } \\
\text { 10.29 } \\
\text { SD: } \\
0.86\end{array}$ & $\begin{array}{l}\text { Mean: } \\
9.51 \\
\text { SD: } \\
0.77\end{array}$ \\
\hline $\begin{array}{l}\text { Gupta, et al. } \\
\text { (2013) }\end{array}$ & $\begin{array}{l}\text { New Delhi, } \\
\text { India, }\end{array}$ & 50 & 50 & Lok Nayak Hospital & $7.0-9.0$ & $\begin{array}{l}\text { IV: iron } \\
\text { sucrose } \\
\text { Oral: ferrous } \\
\text { sulfate }\end{array}$ & $\begin{array}{l}\text { Mean: } \\
9.8 \\
\text { SD: } \\
0.46\end{array}$ & $\begin{array}{l}\text { Mean: } \\
9.18 \\
\text { SD: } \\
0.55\end{array}$ \\
\hline $\begin{array}{l}\text { Kochhar, et } \\
\text { al. (2012) }\end{array}$ & $\begin{array}{l}\text { New Delhi, } \\
\text { India }\end{array}$ & 50 & 50 & $\begin{array}{l}\text { Department of } \\
\text { Obstetrics and } \\
\text { Gynaecology, Lady } \\
\text { Hardinge Medical } \\
\text { College and Smt. } \\
\text { Kucheta Kriplani } \\
\text { Hospital }\end{array}$ & $7.0-9.0$ & $\begin{array}{l}\text { IV: iron } \\
\text { sucrose } \\
\text { Oral: ferrous } \\
\text { sulfate }\end{array}$ & $\begin{array}{c}\text { Mean: } \\
12.8 \\
\text { SD: } \\
1.1\end{array}$ & $\begin{array}{l}\text { Mean: } \\
10.7 \\
\text { SD: } \\
0.7\end{array}$ \\
\hline $\begin{array}{l}\text { Mehta, et al. } \\
(2014)\end{array}$ & India & 75 & 75 & $\begin{array}{l}\text { Department of } \\
\text { Obstetrics and } \\
\text { Gynecology, Surat } \\
\text { Municipal Institute } \\
\text { of Medical Edu- } \\
\text { cation and Study } \\
\text { SMIMER }\end{array}$ & $<8.0$ & $\begin{array}{l}\text { IV: iron } \\
\text { sucrose } \\
\text { Oral: ferrous } \\
\text { sulfate }\end{array}$ & $\begin{array}{c}\text { Mean: } \\
10.64 \\
\text { SD: } \\
0.71\end{array}$ & $\begin{array}{c}\text { Mean: } \\
10.17 \\
\text { SD: } \\
0.54\end{array}$ \\
\hline $\begin{array}{l}\text { Neeru, et al. } \\
(2012)\end{array}$ & India & 45 & 44 & KMC Hospital & $<11.0$ & $\begin{array}{l}\text { IV: iron } \\
\text { sucrose } \\
\text { Oral: ferrous } \\
\text { fumerate }\end{array}$ & $\begin{array}{c}\text { Mean: } \\
11.24 \\
\text { SD: } \\
0.7\end{array}$ & $\begin{array}{l}\text { Mean: } \\
11.06 \\
\text { SD: } \\
0.63\end{array}$ \\
\hline $\begin{array}{l}\text { Rohina, et al. } \\
\text { (2012) }\end{array}$ & $\begin{array}{l}\text { Ahmedaba } \\
\text { d, India }\end{array}$ & 25 & 25 & $\begin{array}{l}\text { Institute of Kidney } \\
\text { Disease and } \\
\text { Study Centre }\end{array}$ & $<7.0$ & $\begin{array}{l}\text { IV: iron } \\
\text { sucrose } \\
\text { Oral: ferrous } \\
\text { sulfate }\end{array}$ & $\begin{array}{c}\text { Mean: } \\
11.3 \\
\text { SD: } \\
0.7\end{array}$ & $\begin{array}{c}\text { Mean: } \\
10.26 \\
\text { SD: } \\
0.77\end{array}$ \\
\hline $\begin{array}{l}\text { Shafi, et al. } \\
\text { (2012) }\end{array}$ & India & $\begin{array}{c}10 \\
0\end{array}$ & 100 & $\begin{array}{l}\text { K.J. Somaiya } \\
\text { Medical College and } \\
\text { Study Centre }\end{array}$ & $6.0-10$ & $\begin{array}{l}\text { IV: iron } \\
\text { sucrose } \\
\text { Oral: ferrous } \\
\text { ascorbate }\end{array}$ & $\begin{array}{l}\text { Mean: } \\
\text { 10.09 } \\
\text { SD: } \\
0.81\end{array}$ & $\begin{array}{c}\text { Mean: } \\
9.32 \\
\text { SD: } \\
0.87\end{array}$ \\
\hline
\end{tabular}

Based on the articles, that was 9 articles that fulfilled the requirements as a source for the meta-analysis of intra-venous iron administration compared to oral iron to increased hemoglobin levels in pregnant women with anemia. Then the articles that ha- 
ve been obtained would be analyzed using RevMan 5.3 and the results would be presented in the form of a forest plot which can be seen in Figure 3 .

The results of the analysis in Figure 3 showed that there were 9 articles reporting that intravenous iron administration was one way that affected the increase in hemoglobin levels in pregnant women with irondeficiency anemia. There was a high heterogeneity between experiments $\left(\mathrm{I}^{2}=91 \%\right.$; $\mathrm{p}$

\begin{tabular}{|c|c|c|c|c|c|c|c|}
\hline \multirow[b]{2}{*}{ Study or Subgroup } & \multicolumn{3}{|c|}{ Intravenous } & \multicolumn{3}{|c|}{ Oral } & \multirow[b]{2}{*}{ Weight } \\
\hline & Mean & SD & Total & Mean & SD & Total & \\
\hline Abhilashini 2014 & 9.48 & 0.7 & 50 & 9.15 & 0.7 & 50 & $11.4 \%$ \\
\hline Bhavi 2017 & 10.64 & 1.3 & 56 & 10.6 & 1.03 & 56 & $10.1 \%$ \\
\hline Dawwish 2017 & 10.29 & 0.86 & 33 & 9.51 & 0.77 & 33 & $10.5 \%$ \\
\hline Gupta 2013 & 9.8 & 0.46 & 50 & 9.18 & 0.55 & 50 & $11.9 \%$ \\
\hline Kochhar 2012 & 12.8 & 1.1 & 50 & 10.7 & 0.7 & 50 & $10.8 \%$ \\
\hline Menta 2014 & 10.64 & 0.71 & 75 & 10.17 & 0.54 & 75 & $11.9 \%$ \\
\hline Neeru 2012 & 11.24 & 0.7 & 45 & 11.06 & 0.63 & 44 & $11.4 \%$ \\
\hline Rohina 2012 & 11.3 & 0.7 & 25 & 10.26 & 0.77 & 25 & $10.4 \%$ \\
\hline Shafi 2012 & 10.09 & 0.81 & 100 & 9.32 & 0.87 & 100 & $11.7 \%$ \\
\hline Total $(95 \% \mathrm{Cl})$ & & & 484 & & & 483 & $100.0 \%$ \\
\hline
\end{tabular}

<0.001) so that Random Effects Model was used. Intravenous iron administration can increase hemoglobin levels $0.70 \mathrm{~g} / \mathrm{dL}$ higher than oral iron administration, which was statistically significant (MD 0.70; CI 95 \%: 0.37 to 1.02 ; $\mathrm{p}<0.001$ ).

Figure 4 effect size of intravenous iron administration compared to oral iron can be seen that the smallest effect size with a score of 0.04 while having a large effect size was 2.10.

Mean Difference

, Random, $95 \% \mathrm{Cl}$

$0.33[0.06,0.60]$

$0.04[-0.39,0.47]$

$0.78[0.39,1.17]$

$0.62[0.42,0.82]$

$2.10[1.74,2.46]$

$0.47[0.27,0.67]$

$0.18[-0.10,0.46]$

$1.04[0.63,1.45]$

$0.77[0.54,1.00]$

$0.70[0.37,1.02]$

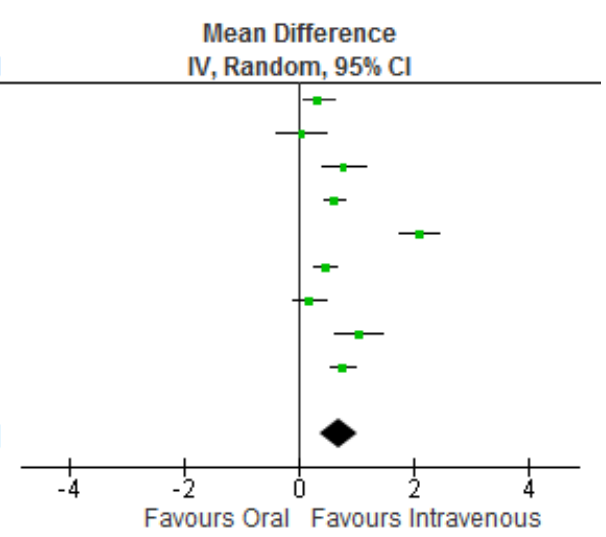

Figure 3.Forest Plot of Intravenous Iron Compared to Oral Iron

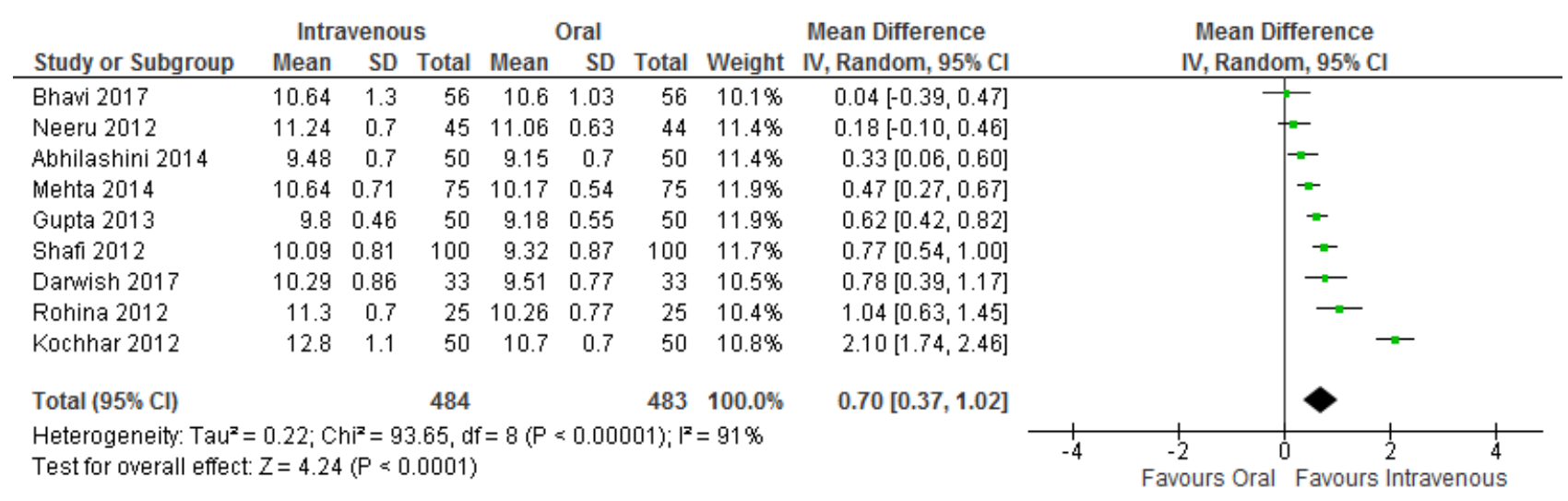

Figure 4. Effect Size of Intravenous Iron Compared to Oral Iron

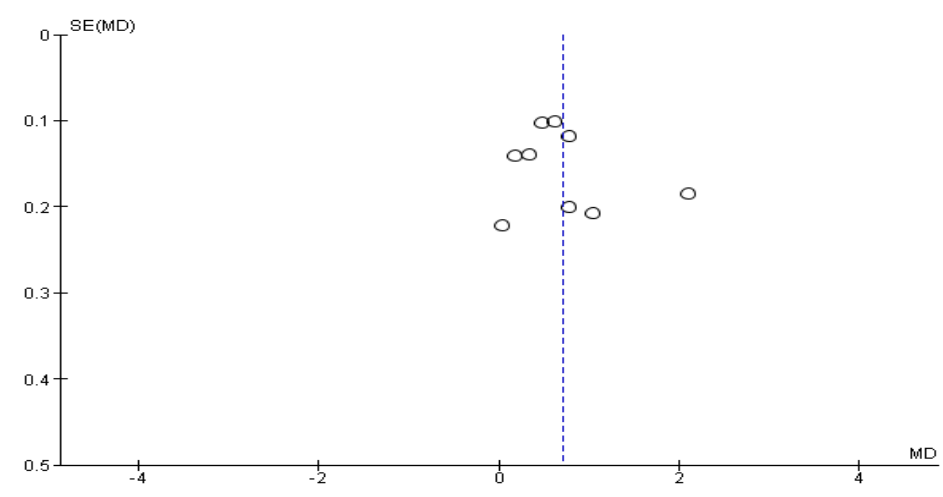

Figure 5. Funnel Plot of Intravenous Iron Compared to Oral Iron 
Funnel plots of intravenous iron and oral iron to increase hemoglobin levels, plots on the right and left sides were not symmetrical with each other and did not form a reverse funnel. The left plot has a standard error $>0.2$ while in the right plot has a standard error of $>0.2$, this indicated that there was a publication bias in the study.

\section{DISCUSSION}

Anemia in pregnancy was a condition of mothers with hemoglobin levels below $11 \mathrm{~g} /$ $\mathrm{dL}$ in the first trimester and third trimester or $<10.5 \mathrm{~g} \%$ in the second trimester (Andriani et al., 2016). Anemia was influenced by many factors, including gestational age, maternal education, family income, pregnancy intervals, parity, increased blood tablet consumption, and history (Prahesti et al., 2016). The occurrence of anemia was not always a diagnosis due to the underlying disease process, technically, anemia was defined as a condition in which an individual hemoglobin concentration in a count of two standard deviations was below the interval reference (Adewoyin, 2015).

The last few years, oral iron, intramuscular and iron iron preparations have been used to treat iron deficiency anemia in pregnancy. The first choice in the treatment of iron deficiency anemia for almost all patients was replacement of oral iron due to its effectiveness, safety, and lower costs (Renzo et al., 2015). The main problem with classic oral iron therapy was poor tolerability and up to $40 \%$ detrimental to the reaction rate (Goonewardene et al., 2012). The most common complaints were nausea, abdominal pain, diarrhea and constipation. Severe systemic side effects associated with dextran iron and iron gluconate which limit intravenous use of iron. Sucrose iron was a relatively new drug, which was used intravenously to treat iron deficiency anemia (Arulkumaran et al., 2011).

The results showed that there were high heterogeneity between experiments (I2 $=91 \% ; \mathrm{p}<0.001)$ so that Random Effects Model (REM) was used. Intravenous iron administration can increase hemoglobin levels by $0.70 \mathrm{~g} / \mathrm{dL}$ higher than oral iron administration, which was statistically significant (MD 0.70; 95\% CI: 0.37 to 1.02; p $<$ o.001). These results were supported by the study of Khalafallah et al. (2010) which stated that intravenous iron was more effective than oral iron for the treatment of anemia in pregnancy iron deficiency. In addition, intravenous iron was safer than oral iron. Devasenapathy et al. (2012) showed that intravenous iron can be a promising therapeutic choice in anemia of pregnancy, in addition, this study stated that intravenous therapy can be an option for increased hemoglobin levels especially in anemia during pregnancy that was severe or required rapid treatment.

In addition to hemoglobin levels, anemia was closely related to economic status. Economic was a determining factor in a healthy pregnancy process. Families with sufficient economies can check their pregnancies on a regular basis, plan delivery at health personnels and do other preparations properly (Kurniati et al., 2016). Health awareness was needed especially during pregnancy to reduce the risk that can occur in the mother and fetus.

\section{AUTHOR CONTRIBUTION}

Fiki Cahya Ningrum, the main author, played a role in collecting and processing study data. Vitri Widyaningsih examined the framework of study concepts and methodologies. Bhisma Murti reviewed the study manuscript. 
FUNDING AND SPONSORSHIP

This study did not received external fundings. This study used secondary data and databases that can be accessed and provided open access journals.

\section{CONFLICT OF INTEREST}

We declare that we do not have any conflict of interest.

\section{ACKNOWLEDGEMENT}

$\overline{\text { We would like to say thank you to database }}$ (PubMed, Science Direct, Springer Link, and Google Scholar) that have provided information and data to published journals.

\section{REFERENCE}

Abhilashini GD, Sagili H, Rani D (2014). Intravenous iron sucrose and oral iron for the treatment of iron deficiency anaemia in pregnancy. Journal Of Clinical and Diagnostic Research. 8(5): OCo4-OCo7. doi: 10.7860/jc$\mathrm{dr} / 2014 / 6568.4382$.

Adewoyin AS (2015). Approach to anaemia, diagnosis in developing countries: focus on aetiology and laboratory workup. Int Blood Res Review. 4(1):1-13. Doi: 10.9734/IBRR/2015/19078.

Andriani Y, Respati SH, Astirin OP (2016). Effectiveness of pregnant woman class in the prevention of pregnancy anemia in Banyuwangi, East Java, Journal of Maternal and Child Health. 1(4): 230241. https://doi.org/10.26911/thejmch.2016.01.04.04.

Arulkumaran S, Regan L, Papageorghiou A, Monga A (2011). Oxford Desk Reference: Obstetrics and Gynaecology. Oxford, UK. Oxford University Press.

Bhavi SB, JajuPB (2017). Intravenous iron sucrose $\mathrm{v} / \mathrm{s}$ oral ferrous fumarate for treatment of anemia in pregnancy. A randomized controlled trial. BMC
Pregnancy and Childbirth, 17(1). doi: 10.1186/s12884-017-1313-9.

Bilimale A, Anjum J, Sangolli HN, Mallapur $M$ (2010). Improving adherence to oral iron supplementation during pregnancy. Maternal Health, Nutrition, Anaemia. 3(5): 281-. 290. doi 10.4066/ AMJ.2010.291.

Camaschella C (2015). Iron-deficiency anemia. New England Journal of Medicine.372(19): 1832-1843. doi: 10.1056/nejmra1401038.

CongdonEL, Westerlund A, Algarin CR, Peirano $\mathrm{PD}$, Gregas $\mathrm{M}$, Lozoff $\mathrm{B}$, Nelson CA (2012). Iron deficiency in infancy is associated with altered neural correlates of recognition memory at 10 years. The Journal of Pediatrics. 16o(6): 1027-1033. doi: 10.1016/j.jpeds.2011.12.011.

Darwish AM, Khalifa EE, Rashad E, Farghally E (2017). Total dose iron dextran infusion versus oral iron for treating iron deficiency anemia in pregnant women: A randomized controlled trial. The Journal of MaternalFetal \& Neonatal Medicine. 32(3): 398-403. doi: 10.1080/14767058.2017.1379988.

Devasenapathy N, Neogi SB, Zodpey S (2012). Is intravenous iron sucrose the treatment of choice for pregnant anemic women?. Journal of Obstetrics and Gynaecology Research. 39(3): 619 626. doi: 10.1111/j.1447-0756.2012.02033.x.

Drukker L, Hants Y, Farkash R, Ruchlemer R, Samueloff A, Grisaru-Granovsky S (2015). Iron deficiency anemia at admission for labor and delivery is associated with an increased risk for Cesarean section and adverse maternal and neonatal outcomes. Transfusion. 55(12): 2799-2806. doi: 10.1111/trf.13252. 
Goonewardene M, Shehata M, Hamad A (2012). Anaemia in pregnancy. Best Practice \& Study Clinical Obstetrics \& Gynaecology. 26(1): 3-24. doi: 10.1016/j.bpobgyn.2011.10.010.

Gupta A, Manaktala U, Rathore AM (2013). A randomised controlled trial to compare intravenous iron sucrose and oral iron in treatment of iron deficiency anemia in pregnancy. Indian Journal of Hematology and Blood Transfusion. 30(2): 120-125. doi: 10.1007/s12288012-0224-1.

Haider BA, Olofin I, Wang M, Spiegelman D, Ezzati M, Fawzi WW (2013). Anaemia, prenatal iron use, and risk of adverse pregnancy outcomes: systematic review and meta-analysis. BMJ. 346(3): f3443-f3443. doi:10.1136/bmj.f3443.

Khalafallah A, Dennis A, Bates J, Bates G, Robertson IK, Smith L, Rasko JEJ (2010). A prospective randomized, controlled trial of intravenous versus oral iron for moderate iron deficiency anaemia of pregnancy. Journal of Internal Medicine. 268(3): 286-295. doi:10.1111/j.1365-2796.2010.02251.x.

Khaskheli M, Baloch S, Baloch AS, Baloch S, Khaskheli FK (2016). Iron deficiency anaemia is still a major killer of pregnant women. Pakistan Journal of Medical Sciences. 32(3): 630-634. doi: 10.12669/pjms.323.9557.

Kochhar PK, Kaundal A, Ghosh P (2012). Intravenous iron sucrose versus oral iron in treatment of iron deficiency anemia in pregnancy: A randomized clinical trial. Journal of Obstetrics and Gynaecology Research. 39(2): 504510. doi:10.1111/j.1447-0756.2012.01982.x.

Kurniati A, Astirin OP, Suryani N (2016). Effect of maternal education, family income, mother-midwife interface, and the incidence of iron deficiency anemia in Pemalang, Central Java, Journal of Maternal of Child Health. 1(4): 220-229. https://doi.org/10.26911/thejmch.2016.01.04.03.

Mehta MN, Shah JM (2014). Iron deficiency anemia in pregnancy: Intravenous versus oral route. Natl J Community Med. 5(1): 10-12. doi: 10.1007/s13224012-0222-0.

Murti B (2018). Prinsip dan metode riset epidemiologi. Edisi IV. Surakarta: Bintang Fajar Offset.

Neeru S, RaiL, Nair N (2012). Iron Sucrose Versus Oral Iron Therapy in Pregnancy Anemia. Indian Journal of Community Medicine. 37(4): 214. doi:10.4103/0970-0218.103467.

Pasricha SR, Drakesmith H, Black J, Hipgrave D, Biggs BA(2013). Control of iron deficiency anemia in low- and middle-income countries. Blood. 121 (14): 2607 2617. doi:10.1182/blood2012-09453522.

Pavord S, Myers B, Robinson S, Allard S, Strong J, Oppenheimer C (2012). UK guidelines on the management of iron deficiency in pregnancy. British Journal of Haematology. 156(5): 588-600. doi:10.1111/j.13652141.2011.09012.x.

Prahesti R, Indarto D, Akhyar M (2016). Analysis of factors associated with anemia in pregnant women at Prambanan Community Health Center, Sleman, Yogyakarta, Journal Maternal and Child Health. 1(2): 131-137. https://doi.org/10.26911/thejmch.201 6.01.02.08.

Qassim A, Mol BW, Grivell RM, Grzeskowiak LE (2017). Safety and efficacy of intravenous iron polymaltose, iron sucrose and ferric carboxymaltose in pregnancy: A systematic review. Australian and New Zealand Journal of 
Obstetrics and Gynaecology. 58(1): 22-39. doi:10.1111/ajo.12695.

Rahman MM, Abe SK, Rahman MS, Kanda M, Narita S, Bilano V, Shibuya K (2016). Maternal anemia and risk of adverse birth and health outcomes in low- and middle-income countries: systematic review and meta-analysis. The American Journal of Clinical Nutrition. 103(2): 495-504. doi:10.3945/ajen.115.107896.

Renzo GCD, Spano F, Giardina I, Brillo E, Clerici G, Roura LC (2015). Iron deficiency anemia in pregnancy. Women's Health. 11(6): 891-900. doi: 10.2217/whe.15.35.

Reveiz L, Gyte GM, Cuervo LG, Casasbuenas A (2011). Treatments for irondeficiency anaemia in pregnancy. Cochrane Database of Systematic Reviews. doi:10.1002/14651858.cdoo3094.pub3.
Rohina A, Mishra VV, Panchal NA, Patel $\mathrm{NH}$, Deshchougule VV, Jasani AF (2012). Evaluation of iron sucrose and oral iron in management of iron deficiency anemia in pregnancy. Natl J Community Med. 1:55-6o. Available at: http://njemindia.org/uploads/31_48-54.pdf.

Shafi D, Purandare SV, Sathe AV (2012). Iron deficiency anemia in pregnancy: intravenous versus oral route. The Journal of Obstetrics and Gynecology of India. 62(3): 317-321. doi:10.1007/s13224-012-0222-0.

Tolkien Z, Stecher L, Mander AP, Pereira DIA, Powell JJ (2015). Ferrous sulfate supplementation causes significant gastrointestinal side-effects in adults: A Systematic Review and Meta-Analysis. PLOS ONE. 10(2): e0117383. doi: 10.1371/journal.pone.0117383. 